Article

\title{
Enhancement of Biodiesel Production from High-Acid-Value Waste Cooking Oil via a Microwave Reactor Using a Homogeneous Alkaline Catalyst ${ }^{\dagger}$
}

\author{
Ming-Chien Hsiao ${ }^{1,2}$, Peir-Horng Liao ${ }^{1}$, Nguyen Vu Lan ${ }^{3}$ and Shuhn-Shyurng Hou $2,4, *$ (D) \\ 1 Department of Environmental Engineering, Kun Shan University, Tainan 71070, Taiwan; \\ johnson@mail.ksu.edu.tw (M.-C.H.); phl2k8@gmail.com (P.-H.L.) \\ 2 Green Energy Technology Research Center, Kun Shan University, Tainan 71070, Taiwan \\ 3 Faculty of Mechanical Engineering, Ho Chi Minh City University of Technology and Education, \\ Ho Chi Minh City 70000, Vietnam; lannv@hcmute.edu.vn \\ 4 Department of Mechanical Engineering, Kun Shan University, Tainan 71070, Taiwan \\ * Correspondence: sshou@mail.ksu.edu.tw; Tel.: +886-6-205-0496 \\ + This article is an extended version of our paper presented in 2019 IEEE International Conference on Applied \\ System Innovation, 11-15 April 2019, Fukuoka, Japan.
}

Citation: Hsiao, M.-C.; Liao, P.-H.; Lan, N.V.; Hou, S.-S. Enhancement of Biodiesel Production from

High-Acid-Value Waste Cooking Oil via a Microwave Reactor Using a Homogeneous Alkaline Catalyst. Energies 2021, 14, 437. https://doi. org/10.3390/en14020437

Received: 25 November 2020 Accepted: 11 January 2021 Published: 15 January 2021

Publisher's Note: MDPI stays neutral with regard to jurisdictional clai$\mathrm{ms}$ in published maps and institutional affiliations.

Copyright: $\odot 2021$ by the authors. Licensee MDPI, Basel, Switzerland. This article is an open access article distributed under the terms and conditions of the Creative Commons Attribution (CC BY) license (https:// creativecommons.org/licenses/by/ $4.0 /)$.

\begin{abstract}
In this study, low quality oils (waste cooking oils) with high acid value (4.81 mg KOH/g) were utilized as the feedstocks for a transesterification reaction enhanced by additional microwave power and the use of an $\mathrm{NaOH}$ catalyst. The kinetics of the transesterification reaction under different reaction times and temperatures was studied. It was found that in the microwave-assisted transesterification reaction, the optimum conditions under a microwave power of $600 \mathrm{~W}$ were as follows: an $\mathrm{NaOH}$ catalyst of $0.8 \mathrm{wt} \%$, a 12:1 molar ratio of methanol to oil, a reaction time of $2 \mathrm{~min}$, and a reaction temperature of $65{ }^{\circ} \mathrm{C}$. The conversion of waste cooking oil into biodiesel reached $98.2 \%$ after this short reaction time. This result conformed to $96.5 \%$ of the standard value of Taiwan CNS 15072. In addition, with increases in the reaction temperature from 55 to $65{ }^{\circ} \mathrm{C}$, the reaction rate constant increased from 0.635 to $2.396 \mathrm{~min}^{-1}$, and the activation energy required for the transesterification reaction was $123.14 \mathrm{~kJ} / \mathrm{mole}$.
\end{abstract}

Keywords: biodiesel; microwave; waste cooking oil; transesterification; high acid value

\section{Introduction}

In the present world, a shortage of energy resources has been foreseen. Fossil fuels are gradually being replaced by sustainable fuels, one of which is biodiesel. One of the most promising methods for sustainable fuels is to convert vegetable oils and other raw materials that mainly contain triglycerides (TGs) and free fatty acids (FFA) into biodiesel [1]. The use of homogeneous catalysts to produce biodiesel has a high conversion rate and a fast reaction, but due to the following reasons, it has some disadvantages in the production of biodiesel: (1) the catalyst has to be neutralized when the reaction is completed and cannot be reused; (2) continuous processing methods are limited; (3) it is technically difficult to remove the catalyst; (4) cleaning and separating products and catalysts will produce a lot of wastewater; and (5) reactant purity and free fatty acids (FFA) content affect the process quite sensitively. Therefore, high-quality feedstocks (for example, refined vegetable oils (RVOs)) are required to prevent undesirable saponification and hydrolysis reactions, or additional reaction processes are required to reduce FFA content [1-3].

The major disadvantage of biodiesel production at present is the high production cost [4], which mainly comes from the cost of RVOs. Using waste cooking oil (WCO) (an inexpensive or sometimes even free raw material) to produce biodiesel is one of the ways to solve this problem. Furthermore, the reuse of WCO is also a solution to waste oil treatment [5,6]. Accordingly, using low-cost feedstocks like high-acid-value oil [4] 
and WCO $[7,8]$ can greatly reduce the production costs related to biodiesel production. However, compared with new oil, WCO has a high FFA content, and therefore requires more extensive transesterification conditions [9].

In general, an alkaline process can produce high-yield biodiesel within $0.5-1 \mathrm{~h}$. However, in this process, only refined vegetable oils with a low acid value (below $2 \mathrm{mg} \mathrm{KOH} / \mathrm{g}$ ) can be utilized as reactants. When the treated oil contains FFA of $2 \mathrm{mg} \mathrm{KOH} / \mathrm{g}$ or more, an acidic process is preferably used because it is simple. In fact, low-cost oils such as WCO and waste fats are the promising desirable feedstocks, but their FFA content is high Using alkaline catalysts, these materials are easy to produce soap, which makes it difficult to separate biodiesel from the glycerol fraction [10]. This problem can be avoided by using an acidic catalyst, where the acids catalyze FFA esterification to generate fatty acid methyl esters (FAMEs), thereby enhancing the yield of biodiesel. Unfortunately, according to [11,12], despite the help of an acidic catalyst, the reaction time can still be as long as $9 \mathrm{~h}$ even if methanol is refluxed, and a high catalyst concentration of about $5 \mathrm{wt} \%$ and a high methanol-to-oil molar ratio of about 40:1 are used. The conversion rate of FAME is as high as $97 \%$ at $95^{\circ} \mathrm{C}$.

Microwave irradiation is an excellent method that can be used to activate polar molecules and ions. This method is thus also very suitable for vegetable oil, which contains methanol and potassium hydroxide, because they have both polar and ionic components. Accordingly, during microwaving, energy is absorbed by these molecules due to ionic movement and dipole rotation. Molecular friction caused by rapid rotation generates heat. It has been proven that microwave-assisted chemical reactions can lead to better synthesis performance as compared to other methods in terms of increasing the reaction rate [13-16]. As reported by [17-19], microwave irradiation increases the reaction rate, thereby achieving high biodiesel yield more quickly. In our previous studies, it was shown that the transesterification of soybean oil can be improved by using an alkali catalyst via ultrasonic mixing and microwave heating methods [20]. Microwave-assisted irradiation also led to dramatic enhancement of the transesterification efficiency of soybean oil used to synthesize biodiesel [21]. More recently, a modified $\mathrm{CaO}$ catalyst was used to improve the transesterification reaction of WCO in a microwave reactor [9]. The reaction time for the synthesis of modified $\mathrm{CaO}$ was found to be greatly reduced by microwave heating. When the transesterification reaction was optimized under the following conditions, the conversion rate of biodiesel was $98.2 \%$ : a catalyst loading of $4 \mathrm{wt} \%$, a methanol/oil molar ratio of $8: 1$, a reaction temperature of $65^{\circ} \mathrm{C}$, and a reaction time over a $75 \mathrm{~min}$ period. Additionally, compared with the traditional water bath typically used in the transesterification reaction, the microwave-assisted method is a more energy-efficient option $[9,22]$.

Factors including the amount of catalyst [22-25], the methanol-to-oil molar ratio [26,27], the reaction temperature [28,29], and the reaction time [30,31], significantly influence the transesterification of WCO. Thus, investigation of these important factors is conducted in this research, where low-value oil (high-acid-value WCO) is converted to biodiesel under microwave-assisted conditions.

Little attention has been paid to the use of advanced microwave technology to produce biodiesel using low-quality oil (WCO) with high acid value as a raw material. This article is of interest as it combines the use of an alternative energy to the microwave method of biodiesel synthesis with the reuse of oils containing a high acidity index. This study also emphasizes the use of a small amount of alkaline catalyst to avoid saponification in the process. Especially, the transesterification kinetics of high-acid-value WCO was also performed under different reaction times and reaction temperatures.

\section{Chemicals, Equipment and Methods}

\subsection{Chemicals}

In this study, the waste cooking oil (WCO) used was gathered from an instant fried chicken shop in Tainan, Taiwan, and its FFA content was about $2.41 \mathrm{wt} \%$. The catalyst used was sodium hydroxide (purity: 98\%) obtained from Mallinckrodt Co., Ltd., St. Louis, 
MO, USA, and the alcohol used was methanol (purity: 99.8\%) acquired from Shimakyu's Pure Chemicals Co., Ltd., Osaka, Japan. Acetate and Methyl laurate were supplied from Tokyo Chemical Industry Co., Ltd., Tokyo, Japan.

\subsection{Equipment}

The reactions were performed using a microwave heating system, as shown in Figure 1. With the help of a catalyst, the reaction mechanism of the transesterification of triglyceride with methanol to synthesize fatty acid methyl esters (FAMEs) is demonstrated in Figure 2. The reactor consists of a continuous microwave power delivery system (with an output power of 0 to $900 \mathrm{~W}$ and an operating frequency of $2.45 \mathrm{GHz}$ ), a time and temperature setting controller, a thermal sensor, and a condenser. The samples were analyzed using a gas chromatography (Clarus 600 Gas Chromatograph/Mass Spectrometer (GC/MS), Perkin Elmer Taiwan Corporation, Taiwan) equipped with a flame ionization detector and a capillary column. The length and inside diameter of the capillary column are $30 \mathrm{~m}$ and $0.25 \mathrm{~mm}$, respectively, with a film thickness of $1.0 \mu \mathrm{m}$.

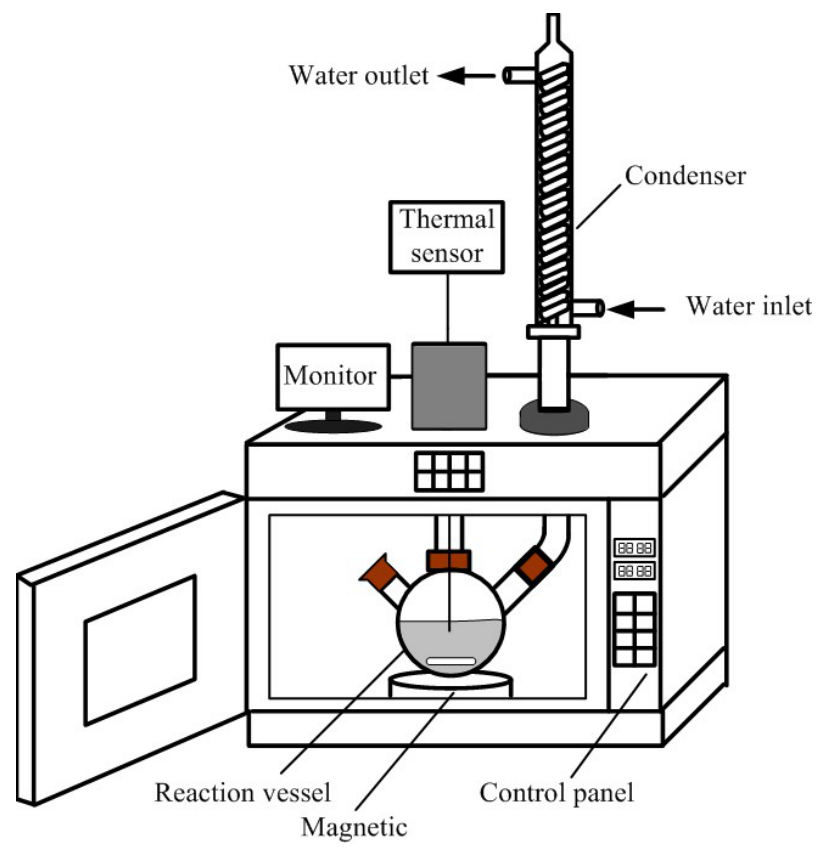

Figure 1. The experimental setup.

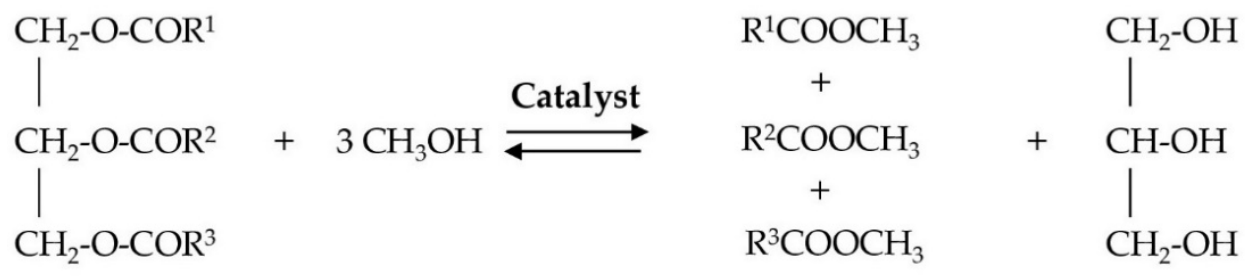

\section{Triglyceride Methanol $\quad$ Fatty acid methyl esters Glycerol}

Figure 2. Transesterification reaction of triglycerides with methanol to synthesize biodiesel and glycerol.

\subsection{Experimental Procedure.}

Methanol and $\mathrm{NaOH}$ catalyst were used to convert triglycerides into esters. Microwave irradiation was utilized to improve the transesterification of WCO. In order to carry out atmospheric pressure experiments, a $250 \mathrm{~mL}$ spherical glass reactor was modified to introduce water condenser. Therefore, cold water could flow through the condenser pipe, 
thereby condensation occurred. A sample of $100 \mathrm{~g}$ WCO was added to a $250 \mathrm{~mL}$ special three-necked reaction flask, and then mixed with methanol and $\mathrm{NaOH}$ catalyst according to the required methanol/oil molar ratio and catalyst loading. The electromagnetic stirrer operated at a fixed stirring speed of $350 \mathrm{rpm}$. In the microwave reactor in a pre-setting procedure, the mixture is automatically heated by microwave irradiation with a power of $600 \mathrm{~W}$. In order to study the important factors affecting the transesterification reaction process, the following experimental parameters were carried out: six methanol-to-oil molar ratios $(3: 1,6: 1,9: 1,12: 1,15: 1$ and $18: 1)$, three reaction temperatures $\left(55,60\right.$, and $\left.65^{\circ} \mathrm{C}\right)$, five reaction times $(1,1.5,2,2.5$, and $3 \mathrm{~min})$, and five amounts of catalyst $(0.2,0.4,0.6,0.8$ and $1.0 \mathrm{w} / \mathrm{w} \%$ of oil).

\subsection{Analytical Methods}

Using a standard titrimetric method based on the standard set by the American Oil Chemists' Society, the saponification value $S V(\mathrm{mg} \mathrm{KOH} / \mathrm{g})$ and acid value $A V(\mathrm{mg}$ $\mathrm{KOH} / \mathrm{g}$ ) of the waste cooking oil were determined. That is, $S V$ can be calculated using Equation (1):

$$
S V=\frac{(B-S) \times 56.1 \times 0.5}{W},
$$

where $B(\mathrm{~mL})$ is the blank titration amount; $S(\mathrm{~mL})$ is the sample titration amount; and $W$ (g) is the weight of oil.

In addition, $A V$ can be determined using the formula below:

$$
A V=\frac{56.1 \times V_{\mathrm{NaOH}}}{W},
$$

where $V_{\mathrm{NaOH}}(\mathrm{mL})$ is the volume of $\mathrm{NaOH}$ titrant used, and $W(\mathrm{~g})$ is the weight of oil.

Equation (3) can be used to calculate the molecular weight $(M W)$ of WCO based on its $S V$ and $A V[32]$ as follows:

$$
M W=56.1 \times 1000 \times \frac{3}{(S V-A V)} .
$$

As a result, the saponification value $(S V)$, acid value $(A V)$, and molecular weight $(M W)$ of the waste cooking oil were determined to be $220.61 \mathrm{mg} \mathrm{KOH} / \mathrm{g}$, $4.81 \mathrm{mg} \mathrm{KOH} / \mathrm{g}$, and $763.02 \mathrm{~g} /$ mole, respectively.

After the completion of the reaction, the reaction mixture was cooled down and transferred to a separatory funnel for phase separation. There were two different phases. The upper phase was composed of FAMEs, while the lower phase was composed of glycerin, excess $\mathrm{NaOH}$ catalyst and alcohol (methanol). Then the lower phase was separated from the upper FAMEs. Subsequently, FAMEs were washed at least 3 times with $30 \%$ acetate and deionized water to remove excess catalyst and methanol. After washing, the methyl ester mixture (biodiesel) was heated for $30 \mathrm{~min}$ to remove entrained moisture/methanol.

Biodiesel samples were analyzed by gas chromatography. First, $50 \mathrm{mg}$ of the internal standard (methyl laurate) was dissolved in $10 \mathrm{~mL}$ of solvent hexane. After mixing $0.5 \mathrm{~g}$ crude biodiesel and the internal standard uniformly, followed the steps below to inject $1 \mu \mathrm{L}$ of the sample into the gas chromatograph for analysis. The inlet temperature was $280^{\circ} \mathrm{C}$, the flow rate of nitrogen (carrier gas) was $45 \mathrm{~mL} / \mathrm{min}$, the air flow rate was $450 \mathrm{~mL} / \mathrm{min}$, the split ratio was $1: 20$, and the detector temperature was $300{ }^{\circ} \mathrm{C}$. The heating program was $210{ }^{\circ} \mathrm{C}$ for $4 \mathrm{~min}$, then the rising speed was $4{ }^{\circ} \mathrm{C} / \mathrm{min}$, and the temperature was raised to $240{ }^{\circ} \mathrm{C}$ for $8 \mathrm{~min}$. Based on the FAME area, Equation (4) can be used to determine the conversion rate of WCO to biodiesel:

$$
\text { Conversion }(\%)=\frac{\left(\frac{\text { area of FAME }}{\text { area of reference }}\right) \times \text { weight of reference }}{\text { weight of crude oil }} \text {. }
$$




\section{Results and Discussion}

\subsection{Effects of Methanol-to-Oil Molar Ratio}

Figure 3 shows the variations in the biodiesel conversion rate based on the changes in the molar ratio of methanol to oil under the preset operating conditions: a reaction time of $2 \mathrm{~min}$, a reaction temperature of $65^{\circ} \mathrm{C}$, a 0.8 or $1.0 \mathrm{wt} \%$ catalyst, and a microwave power of $600 \mathrm{~W}$. With a step of 3:1, the molar ratio was adjusted to vary from 3:1 to 18:1 evenly. Data from Figure 3 reveals an important fact. Within the set range of molar ratio, with increases in the molar ratio, the conversion rate increased continuously with an $\mathrm{NaOH}$ catalyst of $1.0 \mathrm{wt} \%$ while it achieved a maximum value at an intermediate ratio (12:1) with an $\mathrm{NaOH}$ catalyst of $0.8 \mathrm{wt} \%$. The results also showed that, with an $\mathrm{NaOH}$ catalyst of $1.0 \mathrm{wt} \%$, due to the saponification problem occurring at the lowest molar ratio of 3:1, there was a rather low conversion rate of about $71 \%$. However, it was interesting to find that only a little reduction in the amount of $\mathrm{NaOH}$ from $1.0 \mathrm{wt} \%$ to $0.8 \mathrm{wt} \%$ increased the biodiesel yield to more than $90 \%$ since saponification was significantly reduced. The difference between the biodiesel yield with $1.0 \mathrm{wt} \%$ and $0.8 \mathrm{wt} \%$ catalyst $(\mathrm{NaOH})$ in this case was clearly significant. When the molar ratios were increased to 6:1, 9:1, and 12:1, the magnitude of the difference decreased, and it became the most insignificant at the 12:1 molar ratio. Additionally, at this ratio (12:1), the conversion rate with $0.8 \mathrm{wt} \%$ added $\mathrm{NaOH}$ reached its maximum. This was because within this molar ratio range (6:1 to 12:1), the amount of methanol was enough to dissolve the catalyst and support the desired reaction with much less (for the case of $1.0 \mathrm{wt} \%$ ) or even almost no (for the case of $0.8 \mathrm{wt} \%$ ) saponification problem. Nevertheless, with increasing the molar ratio to $15: 1$ and $18: 1$, the conversion rate in the case of the $1.0 \mathrm{wt} \%$ $\mathrm{NaOH}$ differed significantly from that of the case of $0.8 \mathrm{wt} \% \mathrm{NaOH}$. It should be noted that in these two cases, unlike the cases with molar ratios lower than 15:1, the conversion rate with $1.0 \mathrm{wt} \% \mathrm{NaOH}$ was higher (and continued to increase slightly) as compared that with added amount of $\mathrm{NaOH} 0.8 \mathrm{wt} \%$ which was descending from its maximum value. This could be explained that at high molar ratio, the added catalyst was diluted and thus with the case of $0.8 \mathrm{wt} \%$, the catalyst amount became not enough to fulfill its catalyzing effect on the reagents. Interestingly, this problem did not occur in the case at $1.0 \mathrm{wt} \%$. This meant that the optimum added amount of $\mathrm{NaOH}$ should be within a range from 0.8 to $1.0 \mathrm{wt} \%$ (see Figure 4). Therefore, considering the production cost, a 12:1 molar ratio of methanol to oil and an $\mathrm{NaOH}$ catalyst of $0.8 \mathrm{wt} \%$ would be the best choice.

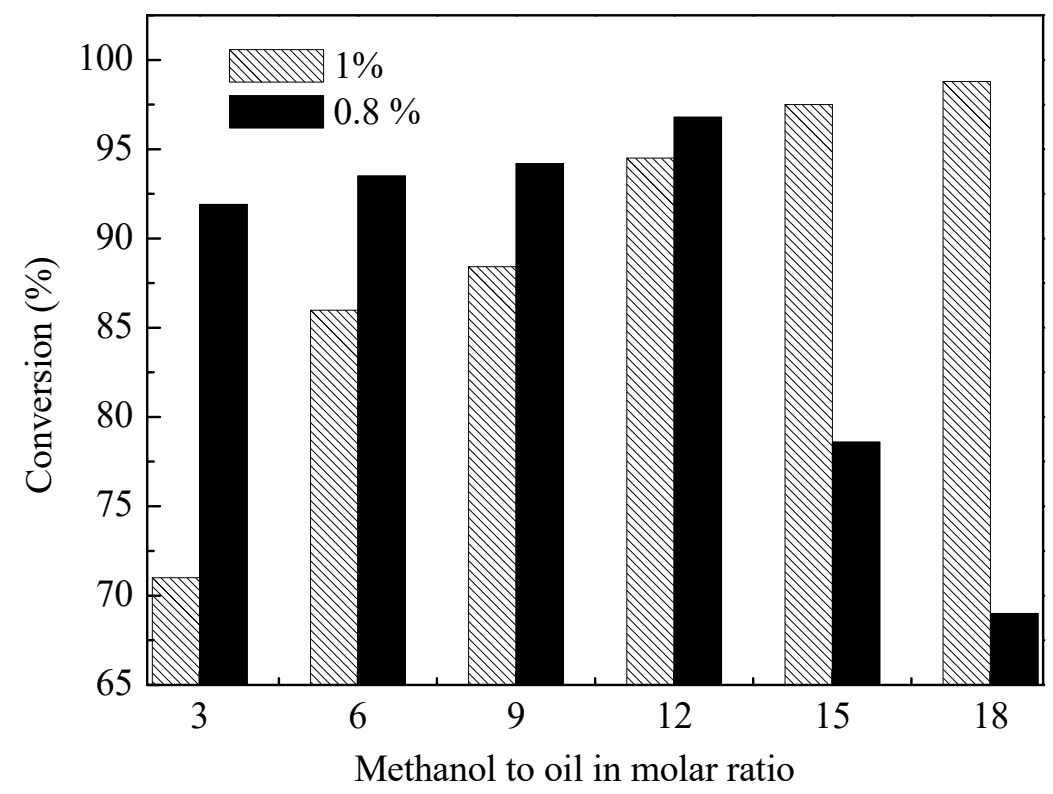

Figure 3. Effects of the molar ratio of methanol to oil on the biodiesel conversion. Reaction conditions at a molar ratio of 3:1-18:1, catalyst at 0.8 and $1.0 \mathrm{wt} \%$, a reaction time of $2 \mathrm{~min}$, a reaction temperature of $65^{\circ} \mathrm{C}$, and a microwave power of $600 \mathrm{~W}$. 


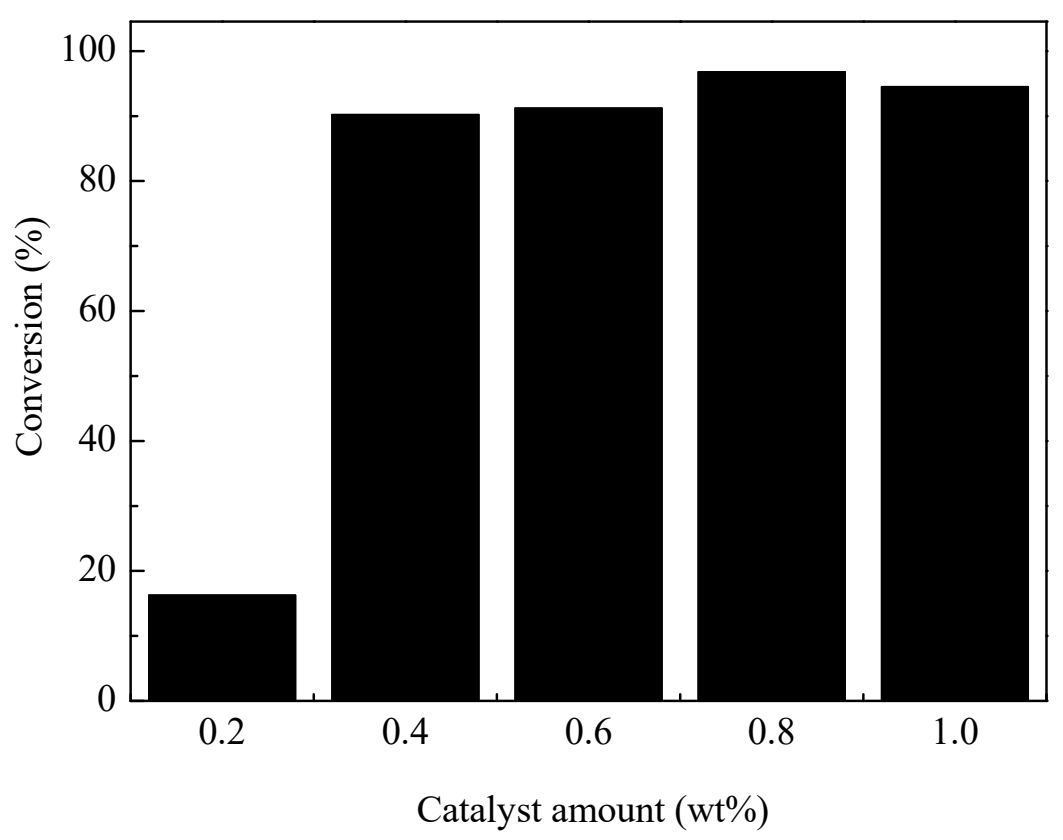

Figure 4. Effects of catalyst amount on the biodiesel conversion. Reaction conditions: a molar ratio of $12: 1$, an $\mathrm{NaOH}$ catalyst ranging from $0.2 \mathrm{wt} \%$ to $1.0 \mathrm{wt} \%$, a reaction time of $2 \mathrm{~min}$, a reaction temperature of $65^{\circ} \mathrm{C}$, and a microwave power of $600 \mathrm{~W}$.

\subsection{Effects of Catalyst Amount}

Figure 4 shows the dependence of the biodiesel conversion rate on catalyst loading. The operating conditions were as follows: a 12:1 molar ratio of methanol to oil, a reaction time of $2 \mathrm{~min}$, a reaction temperature of $65^{\circ} \mathrm{C}$, a microwave power of $600 \mathrm{~W}$, and the catalyst amount varying from 0.2 to $1.0 \mathrm{wt} \%$. With rising the catalyst loading from $0.2 \mathrm{wt} \%$ to $0.4 \mathrm{wt} \%$, the biodiesel conversion rate of $16.3 \%$ increased to $90.2 \%$. Low catalyst concentration resulted in low biodiesel yield. The reason may be because of incomplete reaction and subsequent difficulty in phase separation due to emulsification. With a larger amount of $0.6 \mathrm{wt} \% \mathrm{NaOH}$ catalyst, the conversion rate increased to $91.4 \%$. It is noteworthy that the conversion rate continued to increase to a maximum of $96.8 \%$ as the amount of $\mathrm{NaOH}$ added was $0.8 \mathrm{wt} \%$. However, the conversion rate reduced to $94.5 \%$ as the amount of $\mathrm{NaOH}$ reached $1 \mathrm{wt} \%$. Excessive catalyst is not beneficial to the production of biodiesel due to the increased possibility of saponification, resulting in difficulties in uniform mixing of products. This finding is consistent with the results of Hsiao et al. [9] and Yang et al. [33]. As a result, the most suitable catalyst dosage was determined to be $0.8 \mathrm{wt} \%$ under a 12:1 molar ratio.

\subsection{Effects of Reaction Temperature and Reaction Time}

The conversion rate of biodiesel affected by reaction temperature and reaction time is shown in Figure 5. Different reaction temperatures of $55-65^{\circ} \mathrm{C}$ and reaction times of 1-3 min were investigated. A molar ratio of $12: 1$, an $\mathrm{NaOH}$ catalyst of $0.8 \mathrm{wt} \%$, and an assisting microwave power of $600 \mathrm{~W}$ were used. It was found that the conversion rate at 55 and $60{ }^{\circ} \mathrm{C}$ increased continuously as the reaction time was prolonged. However, for the case at $65{ }^{\circ} \mathrm{C}$, the biodiesel generation reached its maximum of $99.7 \%$ after $2.5 \mathrm{~min}$, which was also the highest rate among all three cases. In order to satisfy the Taiwan CNS 15072 biodiesel standard specification, which requires conversion rate to be more than $96.5 \%$, the conversion rate of $98.4 \%$ could be reached in only $2 \mathrm{~min}$ at $65^{\circ} \mathrm{C}$. The excellent conversion rate obtained at $65^{\circ} \mathrm{C}$ was because the methanol began to boil at this temperature, causing a disturbance in the reaction system, and thus promoted the mixing of the reactants and stimulating the reaction. This useful effect was even multiplied under the microwave assistance to a much greater degree than the cases with lower reaction temperatures. Thus, 
the conversion rate increased to as much as $99.7 \%$ in only $2.5 \mathrm{~min}$ of reaction time. However, extending the reaction time to 3 min resulted in a decrease in the conversion rate. This was mainly because during the redundant reaction time, excessive methanol volatilization resulted in a decrease in the methanol content in the transesterification process. That is, a longer reaction time did not increase the conversion rate of biodiesel. Consequently, at $65^{\circ} \mathrm{C}$, the reaction time was set at $2 \mathrm{~min}$ for the purpose of shortening the reaction time.

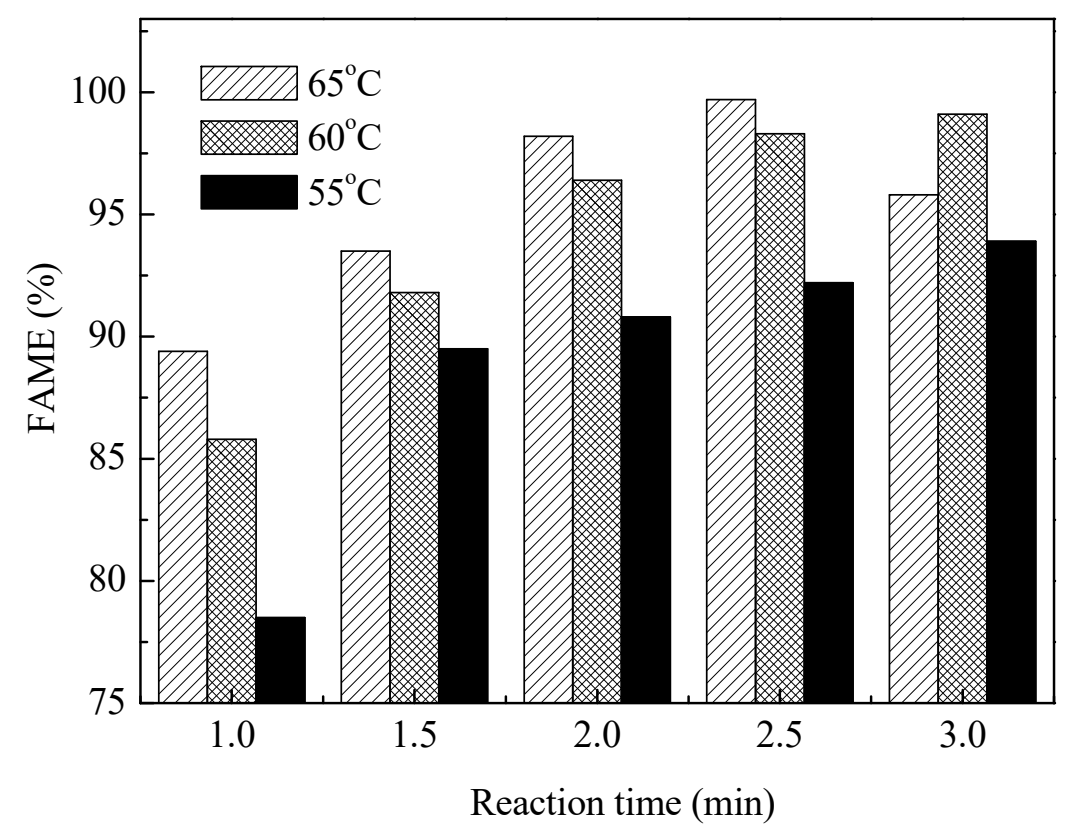

Figure 5. Effects of reaction time and reaction temperature on the biodiesel conversion. Reaction conditions: a 12:1 molar ratio, an $\mathrm{NaOH}$ catalyst of $0.8 \mathrm{wt} \%$, reaction temperatures of 55,60 and $65^{\circ} \mathrm{C}$, a reaction time ranging from 1-3 min, and a microwave power of $600 \mathrm{~W}$.

\subsection{Kinetic Model}

In the present study, the transesterification reaction included only a single direction, where the first-order reaction can be written as:

$$
\mathrm{TG}+3 \mathrm{CH}_{3} \mathrm{OH} \stackrel{k}{\rightarrow} 3 \mathrm{RCOOCH}_{3}+\mathrm{GL}
$$

where TG denotes triglyceride and GL designates glycerine.

The reaction rate constant $k$ could be obtained from Equation (6) as follows:

$$
-\frac{\mathrm{d}[\mathrm{TG}]}{\mathrm{d} t}=k[\mathrm{TG}]
$$

In the actual transesterification reaction, the composition of the reactants was complicated. There were four reactants, including methanol, methyl ester (ME), glycerol (GL), and unreacted matter ( $\mathrm{uME}$ ). The $\mathrm{uME}$ included non-reacted and intermediate substances (e.g., triglycerides, diglycerides, glycerides, and FFAs). Therefore, the reaction could be expressed as:

$$
\mathrm{uME}+3 \mathrm{CH}_{3} \mathrm{OH} \stackrel{k}{\rightarrow} \mathrm{ME}+\mathrm{GL} .
$$

Accordingly, Equation (6) could be rewritten as

$$
-\frac{\mathrm{d}[\mathrm{uME}]}{\mathrm{d} t}=k[\mathrm{uME}] .
$$


Integrating both sides of Equation (8), one can derive:

$$
\ln [\mathrm{uME}, 0]-\ln [\mathrm{uME}, t]=k t .
$$

where $k$ is the reaction rate constant, and [uME, 0$]$ and $[\mathrm{uME}, t]$ represent the concentration of waste cooking oil at the initial time and the concentration of unesterified compounds at time $t$, respectively [34].

According to the calculation results of Equation (9), Figure 6 shows the variations in the concentration of waste cooking oil against time. As can be seen, the value of $k$ could be calculated for different reaction temperatures (see Table 1). Table 1 shows that the reaction rate constant increased with the reaction temperature. The reaction rate constant reached its lowest value $\left(0.635 \mathrm{~min}^{-1}\right)$ at $55^{\circ} \mathrm{C}$, and the highest value $\left(2.396 \mathrm{~min}^{-1}\right)$ at $65^{\circ} \mathrm{C}$. The reason for this change was that the average kinetic energy of the molecule improved at a higher reaction temperature, and therefore, the molecules were better able to create an effective collision.

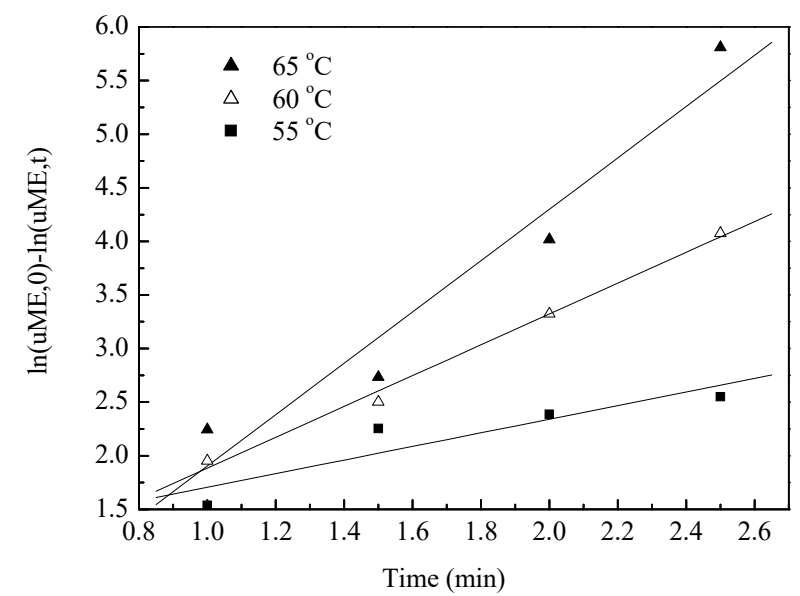

Figure 6. Variations in waste cooking oil concentrations against time at three temperatures. Reaction conditions: a $0.8 \mathrm{wt} \% \mathrm{NaOH}$, a microwave power of $600 \mathrm{~W}$, and a 12:1 molar ratio.

Table 1. Experimental reaction rate constant $(k)$ of the transesterification reaction at different reaction temperatures. Reaction conditions: a methanol-to-oil molar ratio of $12: 1, \mathrm{NaOH}$ at $0.8 \mathrm{wt} \%$, a microwave power of $600 \mathrm{~W}$, and a reaction time of $2 \mathrm{~min}$.

\begin{tabular}{cc}
\hline Temperature $\left({ }^{\circ} \mathbf{C}\right)$ & Reaction Rate Constant $k\left(\mathbf{m i n}^{-1}\right)$ \\
\hline 55 & 0.635 \\
60 & 1.438 \\
65 & 2.396 \\
\hline
\end{tabular}

Consequently, the reaction rate was accelerated. The relationship between the reaction temperature and the reaction rate constant can be expressed as Equation (10) using the Arrhenius equation:

$$
k=A \exp \left(-E_{a} / R T\right)
$$

For the transesterification reaction, the required activation energy cab be estimated using Equation (10). Interpolating the experimental results shown in Table 1 to form the relationship between $\ln k$ versus $1 / T$, a line with a slope of $-E_{a} / R$ would be obtained, as indicated in Figure 7. Specifically, the slope was -14811.47. Thus, applying Equation (10), the activation energy of the esterification process assisted by the external microwave and catalyzed with $\mathrm{NaOH}$ was $123.14 \mathrm{~kJ} /$ mole, recalling that the reaction time was 2 min and the molar ratio was 12:1. 


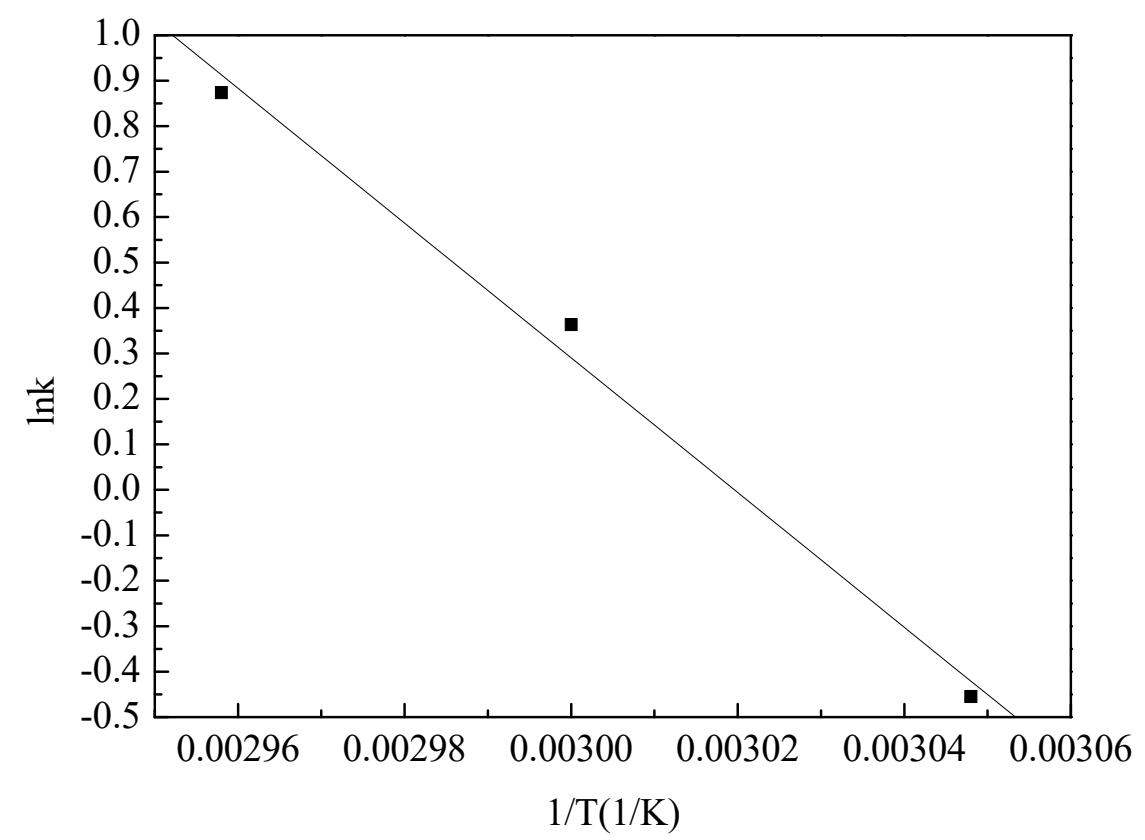

Figure 7. First order reaction rate constant in an Arrhenius plot of waste cooking oil in methanol during the transesterification reaction. Reaction conditions: a 12:1 molar ratio of methanol to oil, $\mathrm{NaOH}$ at $0.8 \mathrm{wt} \%$, a reaction time of $2 \mathrm{~min}$, and a microwave power of $600 \mathrm{~W}$.

\section{Conclusions}

In this study, high-acid-value waste cooking oil was chosen as the raw material for a transesterification microwave-assisted reaction to produce biodiesel. The results showed that the following reaction conditions can be used to obtain a biodiesel yield that meets the Taiwan CNS 15072 biodiesel standard within the shortest time period: an $\mathrm{NaOH}$ catalyst of $0.8 \mathrm{wt} \%$, a 12:1 molar ratio of methanol to oil, a reaction time of $2 \mathrm{~min}$, a reaction temperature of $65{ }^{\circ} \mathrm{C}$, and a microwave power of $600 \mathrm{~W}$. Incremental increases in the molar ratio of methanol to oil, the reaction time, or the catalyst loading will not lead to incremental increases in the conversion rate and will increase production costs. Microwave radiation works best at a reaction temperature of $65^{\circ} \mathrm{C}$ to promote the transesterification process, and the required activation energy is only $123.14 \mathrm{~kJ} / \mathrm{mole}$.

In view of the results obtained in this investigation, we realize that more study on the energy balance to determine the possibility of industrial application of the proposed microwave method is of great significance and worthy of further research.

Author Contributions: M.-C.H., P.-H.L., N.V.L. and S.-S.H. contributed equally to this research, including data collection, result interpretation and analysis, and manuscript preparation; S.-S.H. contributed to the writing and editing of the manuscript. All authors have read and agreed to the published version of the manuscript.

Funding: The authors are grateful to the Ministry of Science and Technology (MOST), Taiwan for its support under grant No. MOST 108-2637-E-168 -010 and MOST 109-2221-E-168 -005 -MY3.

Institutional Review Board Statement: Not applicable.

Informed Consent Statement: Not applicable.

Data Availability Statement: Data is contained within the article.

Conflicts of Interest: The authors declare no conflict of interest. 


\section{References}

1. Lopez, D.E.; Goodwin, J.G.; Bruce, D.A. Transesterification of triacetin with methanol on solid acid and base catalysts. Appl. Catal. A Gen. 2005, 295, 97-105. [CrossRef]

2. Xie, W.; Huang, X.; Li, H. Soybean oil methyl esters preparation using NaX zeolites loaded with $\mathrm{KOH}$ as a heterogeneous catalyst. Bioresour. Technol. 2007, 98, 936-939. [CrossRef] [PubMed]

3. Reddy, C.R.V.; Oshel, R.; Verkade, J.G. Room-temperature conversion of soybean oil and poultry fat to biodiesel catalyzed by nanocrystalline calcium oxides. Energy Fuels 2006, 20, 1310-1314. [CrossRef]

4. Hsiao, M.C.; Kuo, J.Y.; Hsieh, P.H.; Hou, S.S. Improving biodiesel conversions from blends of high-and low-acid-value waste cooking oils using sodium methoxide as a catalyst based on a high speed homogenizer. Energies 2018, 11, 2298. [CrossRef]

5. Zhang, Y.; Dube, M.A.; McLean, D.D.; Kates, M. Biodiesel production from waste cooking oil: 1. process design and technological assessment. Bioresour. Technol. 2003, 89, 1-16. [CrossRef]

6. Marchetti, J.M.; Miguel, V.U.; Errazu, A.F. Heterogeneous esterification of oil with high amount of free fatty acids. Fuel 2005, 86, 906-910. [CrossRef]

7. Hsiao, M.C.; Hou, S.S.; Kuo, J.Y.; Hsieh, P.H. Optimized conversion of waste cooking oil to biodiesel using calcium methoxide as catalyst under homogenizer system conditions. Energies 2018, 11, 2622. [CrossRef]

8. Hsiao, M.C.; Chang, L.W.; Hou, S.S. Study of solid calcium diglyceroxide for biodiesel production from waste cooking oil using a high speed homogenizer. Energies 2019, 12, 3205. [CrossRef]

9. Hsiao, M.C.; Kuo, J.Y.; Hsieh, S.A.; Hsieh, P.H.; Hou, S.S. Optimized conversion of waste cooking oil to biodiesel using modified calcium oxide as catalyst via a microwave heating system. Fuel 2020, 266, 117114. [CrossRef]

10. Lertsathapornsuk, V.; Pairintra, R.; Aryusuk, K.; Krisnangkura, K. Microwave assisted in continuous biodiesel production from waste frying palm oil and its performance in a $100 \mathrm{~kW}$ diesel generator. Fuel Process. Technol. 2008, 89, 1330-1336. [CrossRef]

11. Harrlngton, K.J.; D'Arey-Evans, C. Transesterification in situ of sunflower seed oil. Ind. Eng. Chem. Res. 1985, 24, 314-318. [CrossRef]

12. Charoenchaitrakool, M.; Thienmethangkoon, J. Statistical optimization for biodiesel production from waste frying oil through two-step catalyzed process. Fuel Process. Technol. 2011, 92, 112-118. [CrossRef]

13. Azcan, N.; Danisman, A. Alkali catalyzed transesterification of cottonseed oil by microwave irradiation. Fuel 2007, 86, 2639-2644. [CrossRef]

14. Nayak, M.G.; Vyas, A.P. Optimization of microwave-assisted biodiesel production from Papaya oil using response surface methodology. Renew. Energy 2019, 138, 18-28. [CrossRef]

15. Patil, P.D.; Gude, V.G.; Camacho, L.M.; Deng, S. Microwave-assisted catalytic transesterification of Camelina Sativa oil. Energy Fuels 2010, 2, 1298-1304. [CrossRef]

16. Sharma, A.; Kodgire, P.; Kachhwaha, S.S.; Raghavendra, H.B.; Thakkar, K. Application of microwave energy for biodiesel production using waste cooking oil. Mater. Today 2018, 5, 23064-23075. [CrossRef]

17. Hernando, J.; Leton, P.; Matia, M.P.; Novella, J.L.; Alvarez-Builla, J. Biodiesel and FAME synthesis assisted by microwaves: Homogeneous batch and flow processes. Fuel 2007, 86, 1641-1644. [CrossRef]

18. Leadbeater, N.E.; Stencel, L.M. Fast, easy preparation of biodiesel using microwave heating. Energy Fuels 2006, 20, 2281-2283. [CrossRef]

19. Chen, K.S.; Lin, Y.C.; Hsu, K.H.; Wang, H.K. Improving biodiesel yields from waste cooking oil by using sodium methoxide and a microwave heating system. Energy 2012, 38, 151-156. [CrossRef]

20. Hsiao, M.C.; Lin, C.C.; Chang, Y.H.; Chen, L.C. Ultrasonic mixing and closed microwave irradiation-assisted transesterification of soybean oil. Fuel 2010, 89, 3618-3622. [CrossRef]

21. Hsiao, M.C.; Lin, C.C.; Chang, Y.H. Microwave irradiation-assisted transesterification of soybean oil to biodiesel catalyzed by nanopowder calcium oxide. Fuel 2011, 90, 1963-1967. [CrossRef]

22. Xie, W.; Peng, H.; Chen, L. Transesterification of soybean oil catalyzed by potassium loaded on alumina as a solid-base catalyst. Appl. Catal. A Gen. 2006, 300, 67-74. [CrossRef]

23. Colucci, J.A.; Borrero, E.E.; Alape, F. Biodiesel from an alkaline transesterification reaction of soybean oil using ultrasonic mixing. J. Am. Oil Chem. Soc. 2005, 82, 525-530. [CrossRef]

24. Hanh, H.D.; Dong, N.T.; Starvarache, C.; Okitsu, K.; Maeda, Y.; Nishimura, R. Methanolysis of triolein by low frequency ultrasonic irradiation. Energy Convers. Manag. 2008, 49, 276-280. [CrossRef]

25. Zhang, L.; Xin, Z.; Liu, Z.; Ou, Y.; Ye, Z.; Li, Z.; Wei, G. Microwave-assisted catalytic transfer hydrogenation of biodiesel at constant microwave power. Fuel 2020, 270, 117510. [CrossRef]

26. Gupta, A.R.; Rathod, V.K. Calcium diglyceroxide catalyzed biodiesel production from waste cooking oil in the presence of microwave: Optimization and kinetic studies. Renew. Energy 2018, 121, 757-767. [CrossRef]

27. Lingfeng, C.; Guomin, X.; Bo, X.; Guangyuan, T. Transesterification of cottonseed oil to biodiesel by using heterogeneous solid basic catalysts. Energy Fuels 2007, 21, 3740-3743. [CrossRef]

28. Tan, K.T.; Lee, K.T. Production of FAME by palm oil transesterification via supercritical methanol technology. Biomass Bioenergy 2009, 33, 1096-1099. [CrossRef]

29. Koc, A.B. Ultrasonic monitoring of glycerol settling during transesterification of soybean oil. Bioresour. Technol. 2009, 100, 19-24. 
30. Satyanarayana, M.; Muraleedharan, C. A comparative study of vegetable oil methyl esters (biodiesels). Energy 2011, 36, 2129-2137. [CrossRef]

31. Hanh, H.D.; Dong, N.T.; Okitsu, K.; Nishmura, R.; Maeda, Y. Biodiesel production through transesterification of triolein with various alcohols in an ultrasonic field. Renew. Energy 2009, 34, 766-768. [CrossRef]

32. Anastopoulos, G.; Zannikou, Y.; Stournas, S.; Kalligeros, S. Transesterification of vegetable oils with ethanol and characterization of the key fuel properties of ethyl esters. Energies 2009, 2, 362-376. [CrossRef]

33. Yang, F.X.; Su, Y.Q.; Li, X.H. The research on alkali-refining of Idesia polycarpa var. vestita bites. J. Northwest Univ. 2007, 35, 203-207.

34. He, H.; Sun, S.; Wang, T.; Zhu, S. Transesterification kinetics of soybean oil for production of biodiesel in supercritical methanol. J. Am. Oil Chem. Soc. 2007, 84, 399-404. [CrossRef] 